\title{
Developing of Local Peanut Based on Multiculture That Tolerant to Abiotic and Biotic Conditions With Multigamma Radiation Method (Nuclear)
}

\author{
Bartholomeus Pasangka ${ }^{1} \&$ Refly $^{2}$ \\ ${ }^{1}$ Department of Physics Faculty of Science and Technology, Nusa Cendana University, Kupang, Indonesia \\ ${ }^{2}$ Department of Biology Faculty of Science and Technology, Nusa Cendana University, Kupang, Indonesia \\ Correspondence: Bartholomeus Pasangka, Department of Physics Faculty of Science and Technology, Nusa \\ Cendana University, Kupang, Indonesia. Tel: 62-380-881-597. E-mail: bpasangka15@gmail.com
}

\author{
Received: February 18, 2013 Accepted: March 20, 2013 Online Published: April 15, 2013 \\ doi:10.5539/jas.v5n5p15 \\ URL: http://dx.doi.org/10.5539/jas.v5n5p15
}

\begin{abstract}
The main problems investigated in these research are 1) the developing of local peanut variety from west Sumba through breeding with multigamma radiation method (nuclear) and carefully selection on two varieties of peanut, i.e erect peanut and creep peanut by multiculture principle, in order to obtain the primer seed of local peanut variety that can increase production, 2) developing of primer seed of local yellow corn, in order to tolerant to abiotic and biotic conditions. The main method of research is application of multigamma radiation that supported by other methods comprised of observation/survey, sampling, multiculture, analysis, comparison, and interpretation.

The results of research are two primer varieties of local peanut seed from East Sumba with principle multiculture by multigamma radiation and carefully selection, and the primer seed of sweet local corn that tolerant to abiotic and biotic conditions, in order that production results of peanut's farmer and local corn in East Sumba specially and NNT generally, can significantly optimally increase, to support the stamina and safety of National food. The average production is obtained $5.7 \mathrm{ton} / \mathrm{ha}$ and $4.5 \mathrm{ton} / \mathrm{ha}$ for erect peanut, or the average production increase $43.86 \%$ for creep peanut and $42.22 \%$ for erect peanut.

On the second planting (first cleansing), the research on the second year, obtained the increase of average production about $45.84 \%$ (percent) of dried pod for erect peanut and $46.67 \%$ (percent) of dry pod for creep peanut. The increase of production potential on the second planting, the research on the second year in succession is $52.29 \%$ (percent) dried pod dried pod for erect peanut, and 52.22\% (percent) dried pod for creep peanut. The increase average of production on the second year of research is $40.25 \%$ (percent) dried pod for erect peanut, and $40.42 \%$ (percent) dried pod for creep peanut. The increase average of production potential $48.84 \%$ (percent) dry pod for erect peanut, and $49.95 \%$ (percent) dried pod for creep peanut.
\end{abstract}

Keyword: abiotic-biotic, breeding, developing, multiculture, multigamma

\section{Introduction}

Peanut (Binomial Arachis Hypogaea L) is the second legumes in Indonesia after soybean has an important benefit because it's seed contain high protein and fat (Dean et al., 2009). In 2003, FAO report that oil product of peanut reach to $10 \%$ market of world oil (non crude oil). Peanut suits to be cultivated with multiculture system, because it's illumination limited and can be produced two kinds of commodities in the same time. Multiculture is combination of two or more plants at one area in the same time (Warsana, 2009), like as corn and peanut, corn and soybean, etc.

Peanut generally cultivated by the farmer there are two kinds: 1) creep peanut with characteristics: grow to side direction, the main stem is long, pod on the joints of stem, and genrally has long age. It's grows to creep to all directions in form of circle with diameter up to $150 \mathrm{~cm} .2$ ) erect penut. Characteristics of erect peanut: grow bolt upright, pod on the the joint of stem near clump, the age of plant is short and compact flowered, the average of plant high is $50 \mathrm{~cm}$. On generally, the primer or superior variety of peanut has several physical characteristics (KDMBP2IPT, 2009; PT. Nasa, 2009): 1) high production, 2) the age of plant is shorter (between 85 up to 90 days), 
3) product is stability, 4) tolerant to germ specially viruses (Damicone et al., 2010), 5) tolerant to plant disease like as agromyza, phaedonia inclusa, lamprosema litura, riptortus linearis, etiella zinkkenella, and nezara viridula (Branch et al., 2008; Chapin et al., 2010; Tubbs et al., 2010), 6) tolerant to abioic conditions, 7) the quality of seed increase (content of protein and fat) 8) power of grow is haigh (95\%), 9) shiny skin, 10) water concentration 9\%-12\% (Irwan, 2006). Multigamma radiation technique cause fenotive and genetic effect like as the changing of structure dan composition of chromosome and also molecular of deoxiribo nuclei acid (DNA) on several kinds of plants. Mutation on the plant is spontaneously changed of genetic matters in cells caused by: 1) rearrangement occurred on chromosome structure, 2) changing in genetics, 3) segments duplication of chromosome loss (Darussalam, 1989). The breeding of plant to obtain superior seed variety is necessary chosen efective mutagen i.e mutagen that cause small changing or damage of physiology but large genetic effect on the plant (Isleib et al., 2008; Holbrook et al., 2009; Nigam et al., 2009), like as multigamma or gamma radiation (physical mutagen).

Dosage standard of gamma or multigamma radiation used on breeding of plants according to International Atomic Energy Agency and Darussalam are: 1. Mutation on the plants: 100 rads-3000 rads, 2. Mutation on seeds of plants: 1000 rads-4000 rads, 3. Grow stimulation (cereals plants): 250 rads-1000 rads (IAEA, 2003, 2004, 2006., Darussalam, 1989).

\subsection{Radiation Effect on DNA}

DNA structure formed of double helicks which composed from bundle between phosphate group and dioxiribo sugar that form of strand DNA, and bundle between nitrogen bases which connect to two strands DNA. A large part broken of DNA are broken on bases, bases lost, the bundle between bases has broken, and the bundle of sugar and phosphate has broken, in order that, occurred broken on one strand is called single strand break (ssb).

This damage can be quickly reconstructed without mistake by enzymatic repairs process with using strand DNA that is not break as mold (Bennet, 1996; Hall, 2000). Cell can do the contruction process to the broken of DNA in a few hours, but can be not perfect, mainly to the broken of DNA is called double strends breaks $(\boldsymbol{d} \boldsymbol{s} \boldsymbol{b})$ or break of two strand DNA. The reconstruction process with mistaking causes mutaion of abnormality genetics and chromosome (Bennet, 1996; Hall, 2000). Figure 1, illustrates the broken on DNA as consequnce of radiation.

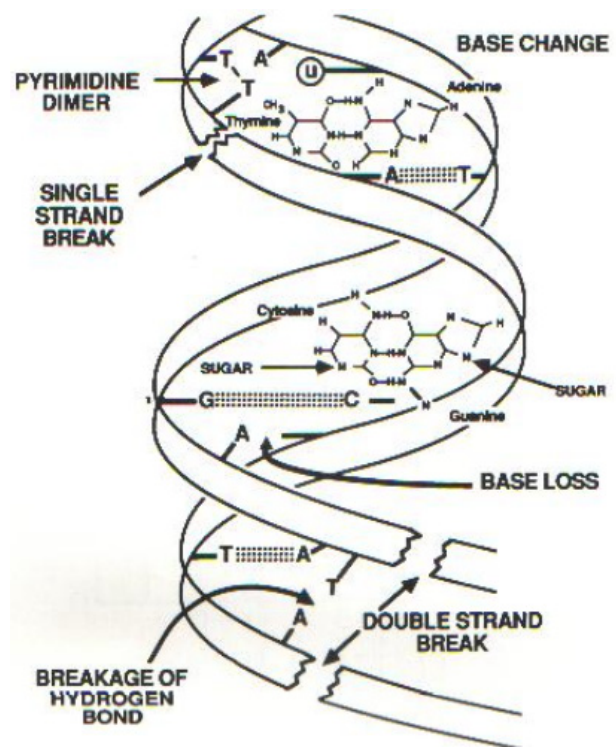

Figure 1. The broken of DNA as consequ-ence of radiation.

\subsection{Radiation Effect on Chromosome.}

Multigamma radaition causes changing of chromosome structure. Normally, chromo-some comprises of upper-arm and fore-arm connected by a centromer. Multigamma radiation causes the forming of: 1) assentric fragment (formed of chromo-some fragment without centromer), 2) disentric chromosome (chromosome has two centromers), 3) ring chromosome, 4) translocation (removal of genetic matter betwen chromosome arm) (Hall, 2000). Fregquency of disentric chromosome and ring increase with creasing of commulative doses on area which 
is high radiation (Crose, 1987). The both effect is important case in breeding of Peanut to oabtain superior seed with specific characteristics.

Production of peanut per hectare is relatively low in every year. It is influenced by soil factor that harder and extreme weather, dry condition, germ, availability of superior seeds, etc. Peanut as a part of food self-supporting of Indonesia is a commodity which still low production in farmer level (Liptan IP2TP, 2004). For increasing these production is needed system completing of peanut cultivation with application of cultivation technology and modern technology for supplying of superior seeds (Domer, 2009). This method is application of multigamma radiation for breeding of local peanut to obtain several superior seeds on multiculture system, that tolerant to abiotic and biotic conditions, specially dry condition, in order that attained optimal production. The supplying of superior seeds of peanut and corn is one problem to the farmer specially in East Sumba, and generally Indonesia, because environment condition factors, like as dry conditions, hard soil, high calcium, high salt, micro and macro-elements are poor, germ, etc. The developing of peanut from East Sumba and corn have an opportunity to obtain superior seeds of peanut and corn that tolerant to those conditions above, in order that can increase production of the farmer in regional or national level.

The superiority of this method is obtained superior seeds variety of plants in relatively short time and there are several superior verieties as a breeding product with characteristics are differenced to initial variety. The aims of these research: 1) to develop local peanut from East Sumba based on multiculture through breeding with multigamma radiation method (nuclear) and carefully selection to obtain two kinds superior seed: a) creep peanut, and b) erect peanut, that tolerant to abaiotic and biotic conditions, 2) to develop primer seed of local yellow corn as a product of multigamma radiation on research in 2009 for incresing of production.

\section{Methods}

The main instruments used in this research comprose of: 1) Multigamma/gamma radiation source, 2) Counter of radiation dose, 3) Analysis equipments of water concentration, fat, and protein, 4) Tractor, 5) Equipments proponent like as: crowbar, mattock, pail, pourer, water tube, germ sprayer, shovel, hammer, saw, etc. Research location in Kupang East Nusa Tenggara at four locations : Bolok, Baumata, Oesao, and Fukdale for the first year, and ten locations for second year: two location at Bolok, two location at Baumata, two locations at Oesao, two locations at Fukdale, and two locations at Bakunase.

The methods of research consist of Observation/ Surveying, sampling, radiation, selection, comparison, and interpretation. The steps of research comprise of: 1) Observation/ surveying to establish location research and selection of two kind samples of local peanut form East Sumba. Observation and measurement several kinds of initial plant of peanut (plant high, mass of 100 pods, plant age, mass of 100 seeds), analysis of protein, fat, and water amount, 2) Design and preparation of sample garden, 3) Peanut sample irradiated by multigamma radiation source on doses 1000 rads-4000 rads and gamma source on dose $0,2 \mathrm{kG}, 4)$ Plant seeds after irradiated with multiculture system, 5) Pour plant necessary while growth, 6) Weed garden and fertilize of plant, 7) Observation and measuring physiscs and chemical characteristics of plant, 8) Harvesting and drying of seeds, 9) To compare physical and chemical characteristics bettwen initial plant and generation plant, interpretate, and conclude of analysis results.

Collecting and data analysis is done through observation that focused on several cases (tolerant to germ, growth at land with haigh calcium, high salt, poor of micro-micro elements, tolerant to dry condition, etc). On harvest period, is done last selection, measuring of plant high and size of pod. After hervest, mass of each group 100 seeds and 100 pods measured. Bihind that, analize protein, fat, and water amount of initial plant and generation plant. The all physical and chemical characteristics and analysis results compared between initial plant and generation plant.

\section{Result and Discussion}

Figure 2, shows two examples growth of local peanut from East Sumba as a result of multigamma radiation on multiculture system. The corn seed used is local sweet yellow corn as the result of multigamma radaition, crossing, and carefully selection on research in 2009 (Pasangka \& Jaelani, 2009). Those examples on Figure 2 show that peanut and corn which grew with multiculture system can be growing rapidly on garden with several conditions laike as dry conditions, high salt, haigh calcium, and poor of macro-micro elements. Figure 3, shows the growth example of generation local peanut on second year research (cleansing). 

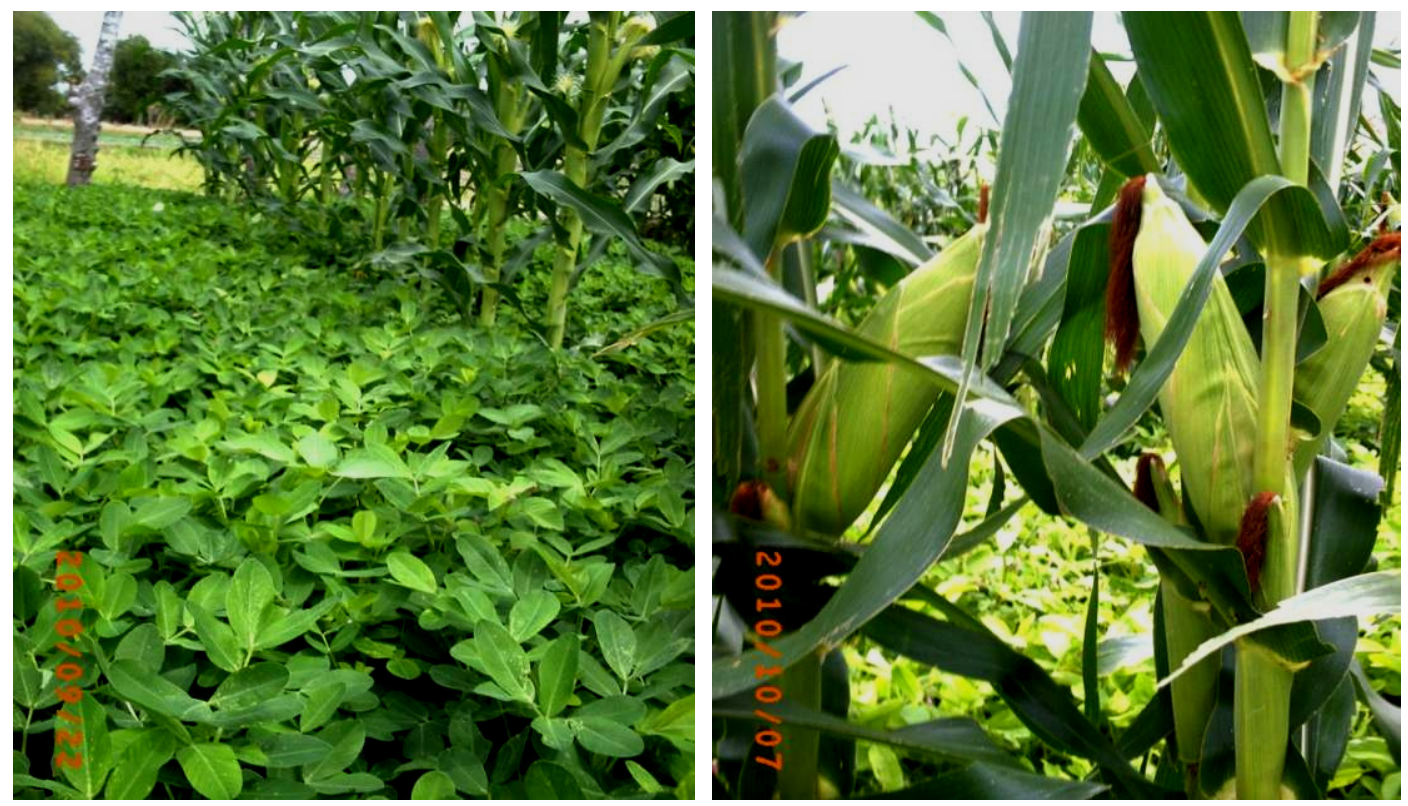

Figure 2. The growth example of local creep peanut as a result of multigamma radiation and superior sweet yellow corn (multiculture) on flowered period until age resemble to young harvest, which fertile grow at garden with high calcium and high salt
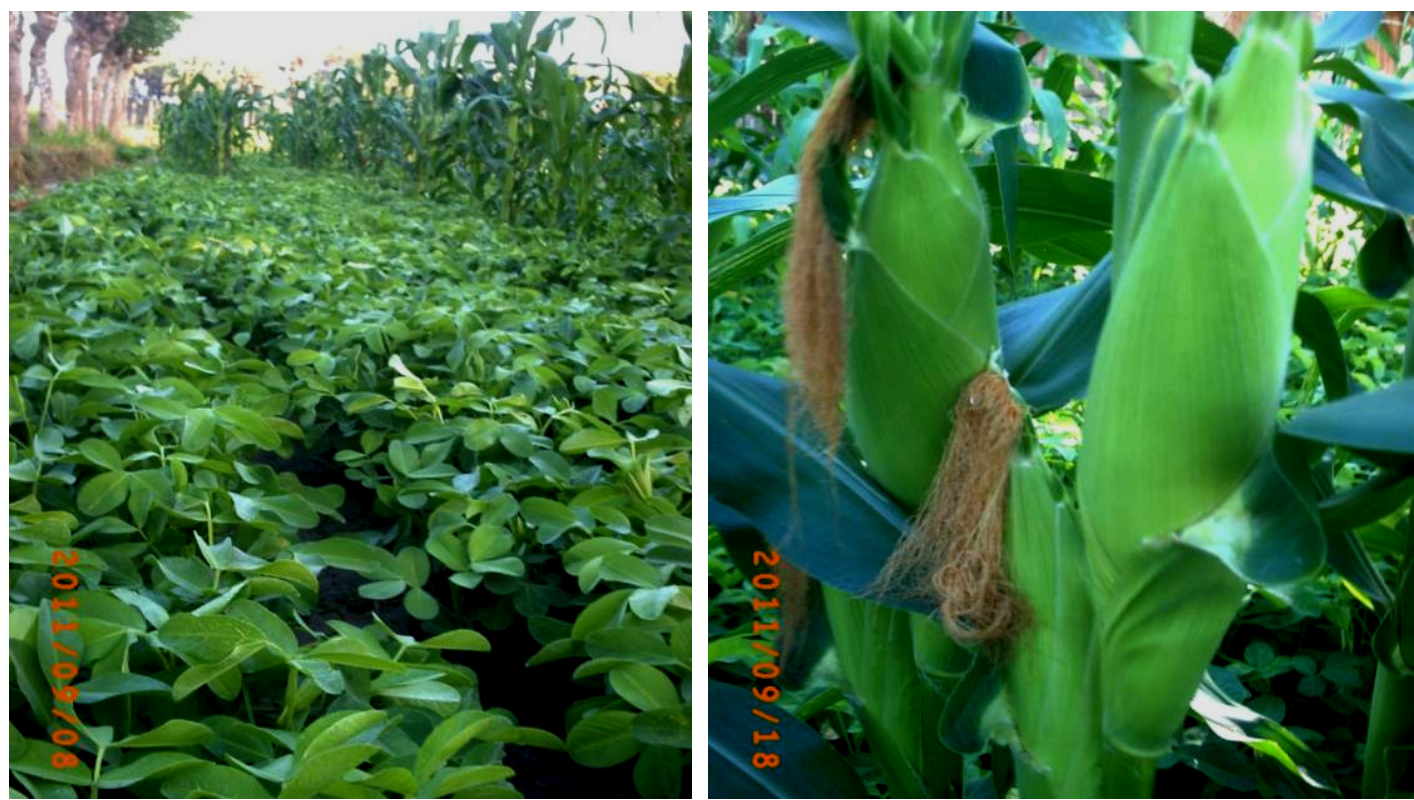

Figure 3. The growth example of generation local peanut on second year research (cleansing)

\section{Observation and Measuring}

Physical and chemical characteristics inspected and measured on local peanut as a result of multigamma radation during research go on included in Table 1, while superior sweet yellow corn included in Table 2. Production of local peanut from East Sumba as a result of multigamma radaition on research in first year included in Table 3, production of local peanut at ten planting locations on first step and the second step of research in second year include in Table 4 and Table 5. Based on data in Table 1, can be proposed that developing of local peanut from East Sumba with multigamma radiation based on multiculture can increase mean production as large as $43.86 \%$ for creep peanut and $42.22 \%$ for erect peanut. Increasing potential of production reach $32.20 \%$ for creep peanut and $27.66 \%$ for erect peanut. Production of corn on multiculture system is 14.85 tons/ha young harvest (research on first year). 
Table 1. Observation and measuring result of physical and chemical characteristics of local peanut as a result of multigaam radiation

\begin{tabular}{|c|c|c|c|}
\hline No & Description & Initial variety & Generation variety \\
\hline 1 & Growth & 10 days after planting (dap) & (4-6) days after planting \\
\hline 2 & Mean sprouting capacity & $88 \%$ & $95 \%$ \\
\hline 3 & $\begin{array}{l}\text { Adaptation at garden with high } \\
\text { calcium and high salt }\end{array}$ & non fertile grow & fertile grow \\
\hline 4 & $\begin{array}{l}\text { Adaptation to dry condition and } \\
\text { poor micro-macro elements. }\end{array}$ & non adapt & adapt \\
\hline 5 & Stem colour & green & green \\
\hline 6 & Leaf colour & green yellowish & green \\
\hline 7 & Flower colour & yellow & yellow \\
\hline 8 & Seeds colour & red- brownish & red-brownish, red, brown \\
\hline 9 & seeds measure & $\begin{array}{l}\text { creep peanut: middle } \\
\text { erect peanut: small }\end{array}$ & creep peanut: large erect peanut: middle \\
\hline 10 & Form of plant & 1) creep 2) erect & 1) creep, 2) erect \\
\hline 11 & Form of seeds & $\begin{array}{l}\text { creep peanut: oval } \\
\text { erect peanut: circle }\end{array}$ & $\begin{array}{l}\text { creep peanut : oval, tapering, pointed } \\
\text { erect peanut: circle, oval }\end{array}$ \\
\hline 12 & Growth & fertile less & fertile \\
\hline 13 & Taste & sweet and deliciously oily & sweet and deliciously oily \\
\hline 14 & Grow type in time flowered & 1) creep, 2) erect & 1) creep, 2) erect \\
\hline 15 & The age of flowered & 26-33 days after planting & 20-33 days after planting \\
\hline 16 & The age of ald pods & $\begin{array}{l}\text { creep peanut: } 180-225 \text { days after } \\
\text { planting, erect peanut: } 92-108 \text { days after } \\
\text { planting }\end{array}$ & $\begin{array}{l}\text { creep peanut: } 105-120 \text { days after } \\
\text { planting, erect penut: } 90-95 \text { days after } \\
\text { planting. }\end{array}$ \\
\hline 17 & Plant high & $\begin{array}{l}\text { creep peanut: } 28 \mathrm{~cm}-51 \mathrm{~cm} \text {, erect } \\
\text { peanut : } 35 \mathrm{~cm}-57 \mathrm{~cm}\end{array}$ & $\begin{array}{l}\text { creep peanut: } 42 \mathrm{~cm}-63 \mathrm{~cm} \\
\text { erect peanut: } 74 \mathrm{~cm}-105 \mathrm{~cm}\end{array}$ \\
\hline 17 & Mean of plant high & $\begin{array}{l}\text { creep peanut: } 39 \mathrm{~cm} \\
\text { creep long: } 25 \mathrm{~cm}-51 \mathrm{~cm} \\
\text { mean crep long: } 40.64 \mathrm{~cm} \\
\text { erect peanut: } 46 \mathrm{~cm}\end{array}$ & $\begin{array}{l}\text { creep paenut: } 53.88 \mathrm{~cm} \\
\text { erect peanut: } 78.60 \mathrm{~cm} \\
\text { creep long: } 59 \mathrm{~cm}-82 \mathrm{~cm} . \\
\text { mean creep long: } 67.14 \mathrm{~cm}\end{array}$ \\
\hline 18 & Form of pods & $\begin{array}{l}\text { creep peanut: rather waist } \\
\text { erect peanut: waist. }\end{array}$ & $\begin{array}{l}\text { creep peanut: rather flat. } \\
\text { erect penaut: rather waist }\end{array}$ \\
\hline 19 & The number of pods per plant & $\begin{array}{l}\text { crep peanut: } 18-36 \text { pods } \\
\text { erect peanut: } 10-31 \text { pods. }\end{array}$ & $\begin{array}{l}\text { creep peanut: } 32-123 \text { pods. } \\
\text { erect peanut: } 25-76 \text { pods. }\end{array}$ \\
\hline 20 & The number of seed per pods & $\begin{array}{l}\text { creep peanut: } 1-2 \text { seeds. } \\
\text { erect peanut: } 1-3 \text { seeds. }\end{array}$ & $\begin{array}{l}\text { Creep peanut: } 1-3 \text { seeds. } \\
\text { erect peanut: } 2-8 \text { seeds. }\end{array}$ \\
\hline 21 & The mean mass per 100 seeds & $\begin{array}{l}\text { creep peanut : } 40.8 \text { grams. } \\
\text { erect peanut: } 38.5 \text { grams. }\end{array}$ & $\begin{array}{l}\text { creep peanut: } 78.7 \text { grams. } \\
\text { erect peanut: } 68.4 \text { grams. }\end{array}$ \\
\hline 22 & The mean mass per 100 pods & $\begin{array}{l}\text { creep peanut: } 142.0 \text { grams. } \\
\text { erect peanut: } 120.2 \text { grams. }\end{array}$ & $\begin{array}{l}\text { creep peanut: } 257.6 \text { grams. } \\
\text { erect penaut: } 249.5 \text { grams. }\end{array}$ \\
\hline 23 & Carbohydrate amount & $\begin{array}{l}\text { creep peanut: } 15.23 \% \\
\text { erect peanut: } 13.84 \%\end{array}$ & $\begin{array}{l}\text { creep peanut: } 15.86 \% \\
\text { erect peanut: } 14.25 \%\end{array}$ \\
\hline 24 & Fat amount & $\begin{array}{l}\text { creep peanut: } 46.12 \% \\
\text { erect peanut: } 33.86 \%\end{array}$ & $\begin{array}{l}\text { creep peanut: } 46.98 \% \\
\text { erect peanut: } 34.18 \%\end{array}$ \\
\hline 25 & Water amount & $(9-12) \%$ & $(8.7-11.9) \%$ \\
\hline 26 & Mean Production & $\begin{array}{l}\text { creep peanut: } 3.2 \text { tons/ha dry pods. } \\
\text { erect peanut: } 2.6 \text { tons/ha (dp). }\end{array}$ & $\begin{array}{l}\text { creep peanut: } 5.7 \text { tons/ ha dry pods }(\mathrm{dp}) \text {. } \\
\text { erect peanut: } 4.5 \text { tons/ha }(\mathrm{pk})\end{array}$ \\
\hline 27 & Potential production & $\begin{array}{l}\text { creep peanut: } 4.0 \text { tons/ha }(\mathrm{dp}) \\
\text { erect peanut: } 3.4 \text { tons/ha }(\mathrm{dp})\end{array}$ & $\begin{array}{l}\text { creep peanut: } 5.9 \text { tons/ ha }(\mathrm{dp}) \\
\text { erect peanut: } 4.7 \text { tons/ha(dp) }\end{array}$ \\
\hline 28 & Adaptation to germ & non adapt. & adapt \\
\hline 29 & $\begin{array}{l}\text { Growth with multiculture } \\
\text { system }\end{array}$ & non fertile and small pods & fertile and large pods \\
\hline
\end{tabular}


Table 2. Observation and mesuring result of physical and chemical characteristics of superior local sweet yellow corn

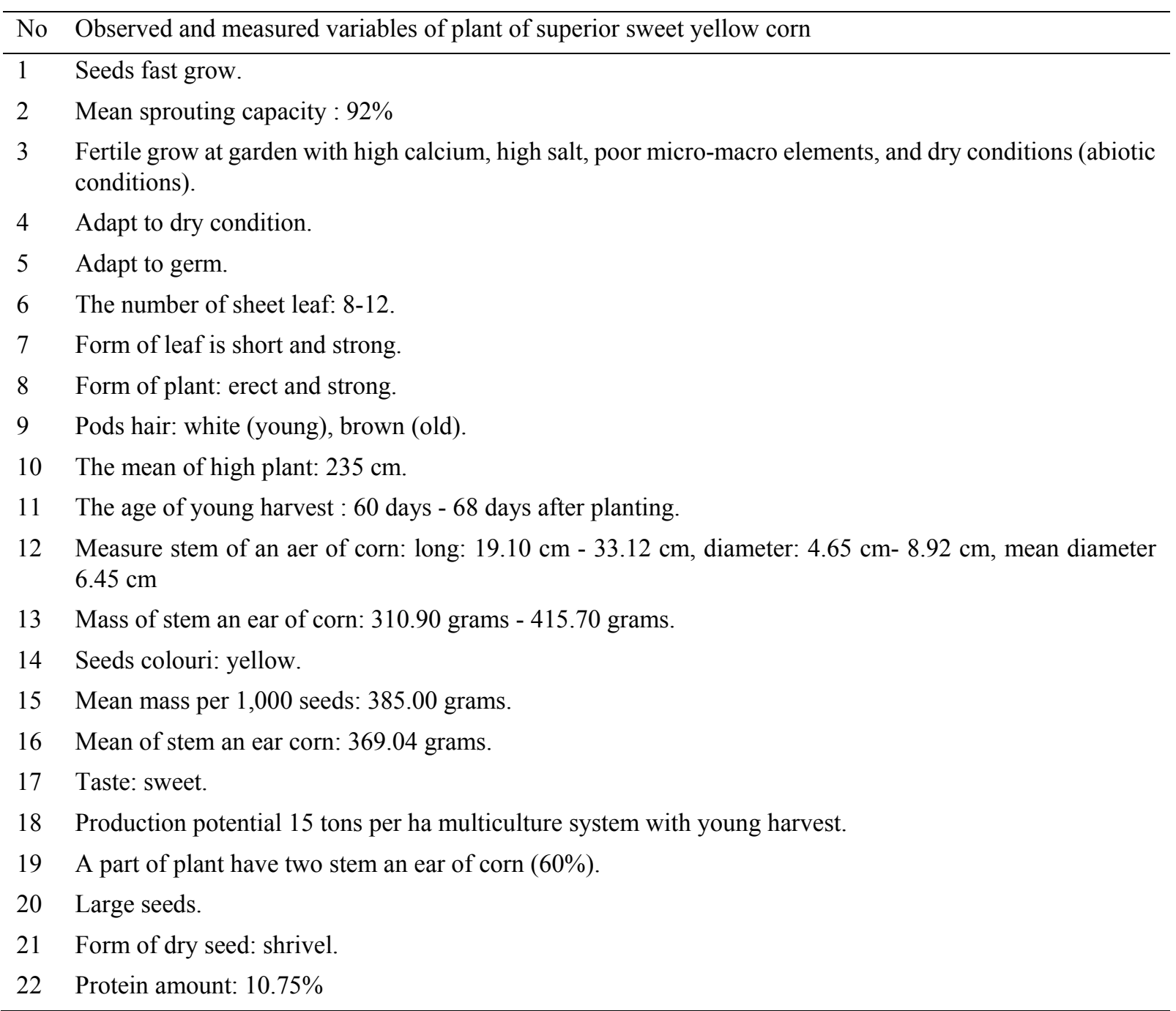

Table 3. Production of local peanut from East Sumba as a result of multigamma radaition on research in first year

\begin{tabular}{|c|c|c|c|c|c|c|c|c|}
\hline Num & Locations & $\begin{array}{l}\text { Kind } \\
\text { peanut }\end{array}$ & of & $\begin{array}{l}\text { Production } \\
\text { (tons/ha) }\end{array}$ & $\begin{array}{l}\text { Mean } \\
\text { (tons/ha) }\end{array}$ & production & $\begin{array}{l}\text { Production } \\
\text { (tons/ha) }\end{array}$ & potential \\
\hline \multirow[t]{2}{*}{1} & Fukdale & Creep & & 5.8 & & & & \\
\hline & & Erect & & 4.6 & & & & \\
\hline \multirow[t]{2}{*}{2} & Baumata & Creep & & 5.5 & 5.7 & & 5.9 & \\
\hline & & Erect & & 4.3 & & & & \\
\hline \multirow[t]{2}{*}{3} & Bolok & Creep & & 5.6 & & & & \\
\hline & & Erect & & 4.4 & 4.5 & & 4.7 & \\
\hline \multirow[t]{2}{*}{4} & Oesao & Creep & & 5.9 & & & & \\
\hline & & Erect & & 4.7 & & & & \\
\hline
\end{tabular}


Table 4. Production of local peanut at ten planting locations on first step of research in second year

\begin{tabular}{|c|c|c|c|c|c|c|}
\hline Num. & Locations & Kinds of peanut & $\begin{array}{l}\text { Production } \\
\text { (tons/ha) }\end{array}$ & $\begin{array}{ll}\text { Mean } & \text { production } \\
\text { (tons/ha) } & \end{array}$ & $\begin{array}{l}\text { Production } \\
\text { (tons/ha) }\end{array}$ & potential \\
\hline \multirow{2}{*}{1} & \multirow{2}{*}{ Bolok (2) } & Creep & 4.40 & & & \\
\hline & & Erect & 3.46 & & & \\
\hline \multirow{2}{*}{2} & \multirow{2}{*}{ Baumata (2) } & Creep & 4.30 & 4.86 & 6.00 & \\
\hline & & Erect & 3.50 & & & \\
\hline \multirow{2}{*}{3} & \multirow{2}{*}{ Bakunase (2) } & Creep & 4.50 & & & \\
\hline & & Erect & 3.53 & & & \\
\hline \multirow{2}{*}{4} & \multirow{2}{*}{ Oesao (2) } & Creep & 5.10 & & & \\
\hline & & Erect & 4.62 & 3.98 & 4.80 & \\
\hline \multirow{2}{*}{5} & \multirow{2}{*}{ Fukdale (2) } & Creep & 6.00 & & & \\
\hline & & Erect & 4.80 & & & \\
\hline
\end{tabular}

Table 5. Production of local peanut at ten planting locations on second step of research in second year (first cleansing)

\begin{tabular}{|c|c|c|c|c|c|c|}
\hline Num & Locations & $\begin{array}{l}\text { Kinds of } \\
\text { peanut }\end{array}$ & $\begin{array}{l}\text { Production } \\
\text { (tons/ha) }\end{array}$ & $\begin{array}{ll}\text { Mean } & \text { production } \\
\text { (tons/ha) } & \end{array}$ & $\begin{array}{l}\text { Production } \\
\text { (tons/ha) }\end{array}$ & potential \\
\hline \multirow{2}{*}{1} & \multirow{2}{*}{ Bolok (2) } & Creep & 4.75 & & & \\
\hline & & Erect & 4.12 & & & \\
\hline \multirow{2}{*}{2} & \multirow{2}{*}{ Baumata (2) } & Creep & 4.80 & 5.46 & 6.84 & \\
\hline & & Erect & 3.95 & & & \\
\hline \multirow{2}{*}{3} & \multirow{2}{*}{ Bakunase (2) } & Creep & 5.20 & & & \\
\hline & & Erect & 4.25 & & & \\
\hline \multirow{2}{*}{4} & \multirow{2}{*}{ Oesao (2) } & Creep & 5.70 & & & \\
\hline & & Erect & 5.12 & 4.58 & 5.45 & \\
\hline \multirow{2}{*}{5} & \multirow{2}{*}{ Fukdale (2) } & Creep & 6.84 & & & \\
\hline & & Erect & 5.45 & & & \\
\hline
\end{tabular}

Figure 4a, shows pods still hang on it's stem which dominated 3-4 seeds per pod with the number of pods per tree revolve between 25 up to 76 . The main production of peanut from East Sumba as a result of multigmma radiation reached at four planting location with multiculture system is 5.7 tons/ha for creep peanut and 4.5 tons/ha for erect peanut. Production interval reached at four planting location: 5.5 tons/ha up to 5.9 tons/ha for creep peanut and 4.3 tons/ha up to 4.7 tons/ha for erect peanut. Maximum product potential is 5.9 tons/ha for creep peanut and 4.7 tons/ha for erect peanut (Research on first step, the second year). 


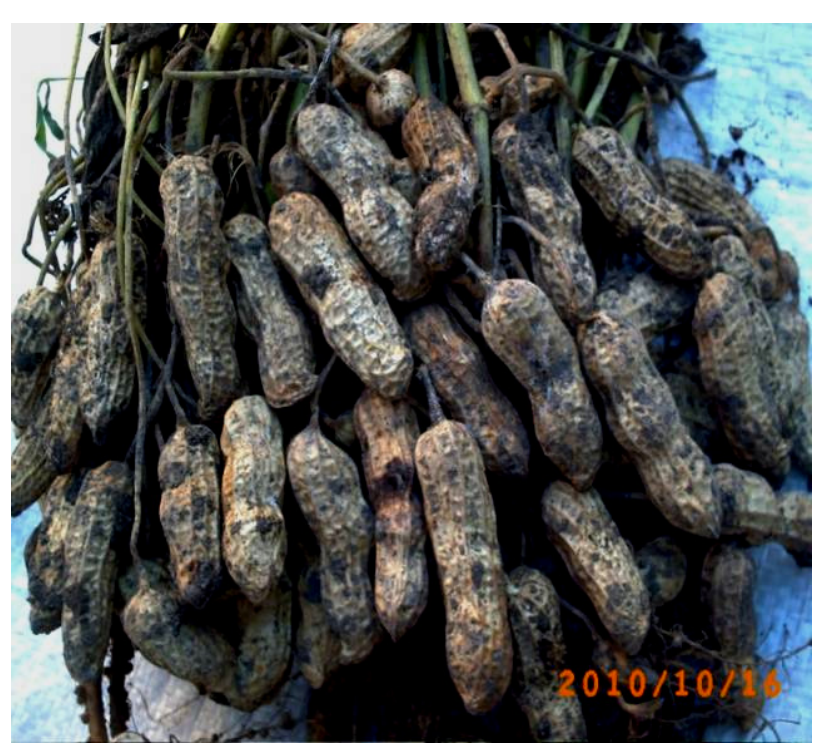

Figure 4a. Generation erect peanut

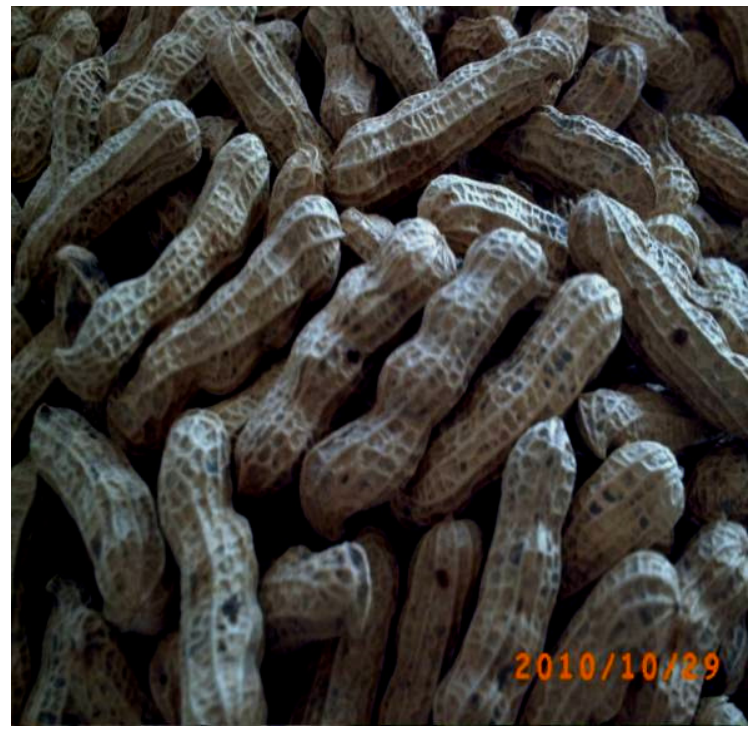

Figure $4 b$. Generation erect peanut

Figure 4a. The example of erect local peanut from East Sumba as a result of multigamma radiation has harversted, It shows pods to be dominated by four seeds per pod about $55 \%$ and three seed per pod about $35 \%$, and $10 \%$ two seeds per pod. The number of pods per tree revolve between 25 up to 76 pods, the age of harvest about $90-95$ dys after planted. Figure $4 \mathrm{~b}$ shows the example of erect local peanut as a result of multigamma radiation has harversted with four seeds per pod and compact contents.

Figure 5a shows example of creep local peanut from East Sumba as a result of multigamma radiation has harvested with two seeds per pod, compact contents, and large seed. Figure $5 \mathrm{~b}$ is example of seeds of creep local peanut as a result of multigamma radiation which carefully selected for continuously developing. Figure 6 shows example of superior local corn (sweet yellow corn) selected for continuously developing with multiculture system.

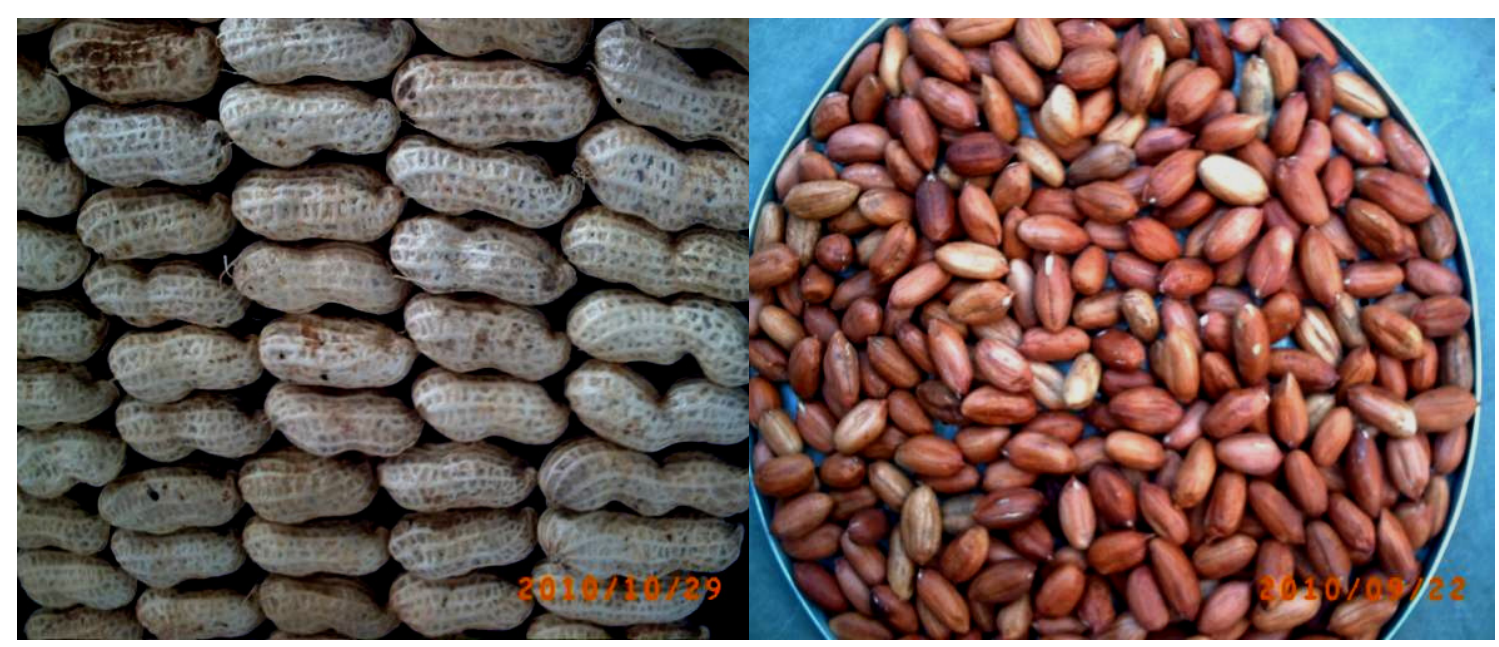

Figure 5a. Pods of generation creep peanut

Figure $5 \mathrm{~b}$. Seeds of generation creep peanut 

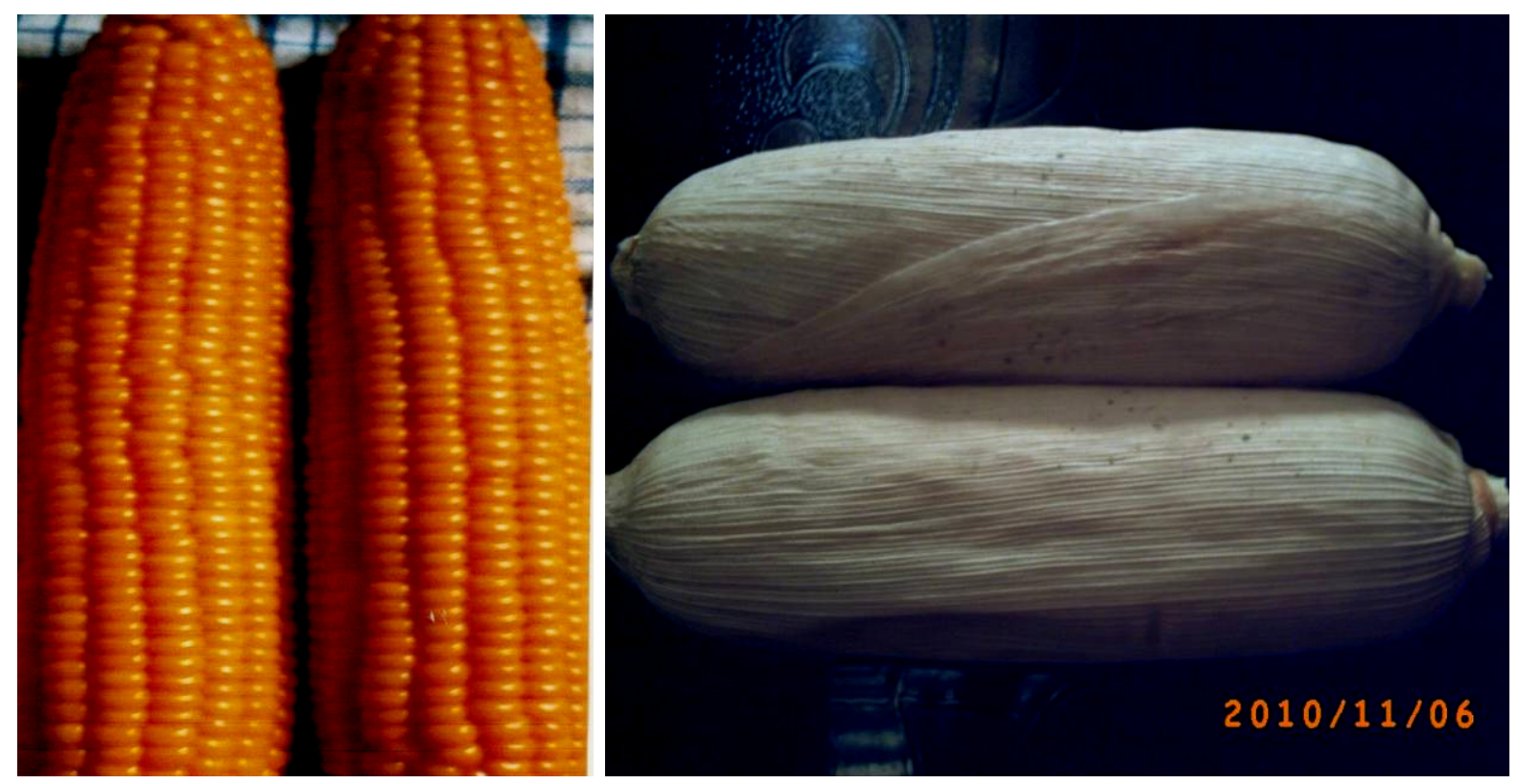

Figure 6. Superior sweet yellow corn as a result of multigamma radiation (local corn)

The results of observation and measuring of physical and chemical characteristics show that local creep peanut and local erect peanut from East Sumba that developed with multigamma radiation on multiculture system, tolerant to abiotik conditions like as dry conditions, high salt, high calcium, and poor of micro-macro elements, and tolerant to biotic conditions like as germ. Based on data in Table 1 and Table 2, can be proposed that seeds of local peanut from East Sumba as a result of multigamma radiation have grow power is higher than initial local peanut and growth is more quickly than initial local peanut, flowered time is qucikly and harvest time is more quickly than initial peanut. Economizing time obtained as large as $41.67 \%$ up to $46.70 \%$ for superior creep peanut and $2.17 \%$ up to $12.04 \%$ for superior erect peanut.

\subsection{Tolerant to Germ}

Based on observation results from firts growth until to harvest time clearly shown that growth of superior local peanut tolerant to germ. This case is shown by soft leaf sisnce growth on both kinds of peanut.

\subsection{Adaptation Characteristics}

On first step and the second step planting ofresearch in second year is shown that the both kinds of superior peanut as a result of multigamma radiation for all varieties chosen, growing rapidly at several conditions laike as dry condition, high salt, high calcium, etc.

\subsection{Grow Ability}

Superior seeds of peanut have mean grow ability about $96 \%$ and superior seeds of sweet yellow corn about $92 \%$. The grow ability of initial peanut: $88 \%$. It is shows the increase of grow ability as big as $9.05 \%$ on the all varieties of superior local peanut as a result of multigamma radaition.

\subsection{The Increase of Production}

Production of superior varieties of peanut significantly increase, i.e the increase of mean production is $42.22 \%$ dry pods for erect peanut and $31.91 \%$ dry pods for creep peanut (research on the first year). On the first step planting of research in second year obtained potential increasing production $29.17 \%$ dry pods for erect peanut, and $33.33 \%$ dry pods for creep peanut. On the second step planting of researh in second year (first cleansing) obtained increase of mean production $43.23 \%$ dry pods for erect peanut and $41.39 \%$ dry pods for creep peanut. Production potential increasing on second step planting of research in second year is $37.61 \%$ dry pods for erect peanut and $41.52 \%$ dry pods for creep peanut. The increasing of mean production of research on second year about $38.95 \%$ dry pods for erect peanut and $37.78 \%$ dry pods for creep peanut. The mean increasing potential $33.39 \%$ dry pods for erect peanut and $37.43 \%$ dry pods for creep penut. The increasing of corn is also significantly, i.e 15 tons/ha young harvest (multiculture system). 


\subsection{Conclusion and Suggestion}

Based on explain above, can be proposed conclussion: 1) Developing of local peanut based on multiculture with multigamma radaition and carefully selection can increase mean production of the peanut as big as $40.59 \%$ dry pods for erect penaut and $34.85 \%$ dry pods for creep peanut (mean production: 4.39 tons/ha dry pods for erect peanut and 4.93 tons/ha dry pods for creep penaut). 2) Developing of local peanut based on multiculture with multigamma radaition (nuclear) and carefully selection produces superior local peanut and has a certain quality with physical and chemical caharacteristic complete. There are several varieties of primer seed obtained in this research. The researcher suggest in order that the all varieties can be continuously developed to obtain superior seed of peanut to be cultivated as widespread as possible by the farmers.

\section{Acknowledgement}

This research or study was supported (Funded) by by National Strategy Research, Directorate of Reseach and Publc Service, Department of Education and Culture of Indonesia Goverment, 2010/2011 and 2011/2012 (two years).

\section{References}

Bennet, B G. (1996). In High Levels of Natural Radiation. Radiation Dose and Health Effects.

Branch, W. D., Culbreath, A. K., \& Gorbet, D. W. (2008). Disease and Insect Assessment of Candidate Cultivars for Potential Use in Organic Peanut Production. Peanut Science, 35(1), 61-66. http://dx.doi.org/10.3146/PS07-016.1

Chapin, J. W., James, S. T., Thomas G. I., Fredrik M. S., William D. B., \& Barry L. T. (2010). Field Evaluation Virginia- Type Peanut Cultivars for Resistance to Tomato Spotted Wilt Virus, Late Leaf Spot, and Stem Rod. Peanut Science, 37(1), 63-69. http://dx.doi.org/10.3146/PS09-007.1

Croce, C. M. (1987). Role of Chromosome Translocations in Human Neoplasia. Cell, 49. http://dx.doi.org/10.1016/0092-8674(87)90552-6

Damicone, J. P., Holbrook, C. C., Smith, D. L., Melouk, W. A., \& Chmberlin, K. D. (2010). Reaction of the Core Collection of Peanut Germplasm to Sclerotimia Bright and Popper Spot 1. Peanut Science, 37(1), 1-11. http://dx.doi.org/10.3146/PS09-001.1

Darussalam, M. (1989). Radiation and Radioisotope, Principal Application in Biology, Medicine, and Agriculture. Published by Tarsito bandung.

Dean, L. L., Hendrix, K. W., Holbrook, C. C., \& Sanders, T. H. (2009). Content of Some Nutrients in the Core of the Core of the Peanut Germplasm Collection. Peanut Science, 36(2), 104-120. http://dx.doi.org/10.3146/PS07-103.1

Domer, J. W. (2009). Development of Biocontrol Technology to Manage Aflatoxin Contamination in Peanut. Peanut Science, 36(1), 54-59.

Hall E. J. (2000). Radiobiology for the Radiologist (3rd ed.). USA: Lippincott William \& Wilkins, Philadelphia.

Holbrook, C. C., Guo, B. Z., Wilson, D. M., Timper, P. (2009). The U. S. Breeding Program to Develop Peanut with Drought Tolerance and Reduced Aflatoxin Contamination. Peanut Science, 36(1), 50-53. http://dx.doi.org/10.3146/AT07-009.1

IAEA. (2003). Rice Breeding with Induced Mutation. Journal of Tech. Reports Series, Vienna, 125, 95-102.

IAEA. (2004). Radiation Safety of Gamma and Electron Irradiation Facilities. Journal of Safety Series, Vienna, 101, 71-98.

IAEA. (2006). Preservation of Fruit and Vegetables by Radiation. Journal of Safety Standards Series, Vienna, 103, 75-93.

Isleib, T. G., Tillman, B. L., Pattee, H. E., Sanders, T. H., Hendrik, K. W., \& Dean, L. O. (2008). Genotype-by-Environment Interactions for Seed Composition Traits of Breeding Lines in the Uniform Peanut Performance Test. Penut Science, 35(2), 130-138. http://dx.doi.org/10.3146/PS08-001.1

KDMBBP2IPT. (2009). Cultivation Technique of Peanut. Research Institution of FoodPlants. Agriculture Service Regency of Bantul Yogyakarta.

Liptan IP2TP. (2004). Technology Package of Peanut cultivation advice at dry area. Research institution of food crop. Mataram NTB. 
Nigam, S. N., Waliyar, F., Aruna, R., Reddy, S. V., Lava Kumar, P., \& Craefurd, P. Q. (2009). Breeding Peanut for Resistance to Aflatoxin Contamination at ICRISAT. Peanut Science, 36(1), $42-49$. http://dx.doi.org/10.3146/AT07-008.1

Pasangaka, B., \& dan Jaelani, A. K. (2009). The Breeding of Local by Multigamma Radiation Method (Nuclear) in West Timor Nusa Tenggara Timur. Jurnal Teknologi TECHNOSCIENTA, 3(1).

PT Nasa. (2009). Qualitaively and Quantitatively Developing of Peanut with Cultivation of Environment Conservation.

Tubbs, R. S., Prostko, E. P., Kemerait, C. C., Brenneman, T. B., \& Wann, D. Q. (2010). Influence of Paraquat Yield and Tomato Spotted Wilt Virus for Georgia O2C and Georgia O3L Peanut. Peanut Science, 37(1), 39-43.

Warsana. (2009). Introduction Technology of Multiculture: Corn and Peanut. BPTP Middle Java, Jurnal Tabloid Sinar Sari. 